Cornell University Law School Scholarship@Cornell Law: A Digital Repository

1993

\title{
The Neumeier-Schultz Rules: How Logical a "Next Stage in the Evolution of the Law" after Babcock?
}

Gary J. Simson

Cornell Law School, simson@law.mail.cornell.edu

Follow this and additional works at: https://scholarship.law.cornell.edu/facpub

Part of the Civil Procedure Commons, Jurisdiction Commons, and the Torts Commons

\section{Recommended Citation}

Simson, Gary J., "The Neumeier-Schultz Rules: How Logical a "Next Stage in the Evolution of the Law" after Babcock?" (1993). Cornell Law Faculty Publications. 1635.

https://scholarship.law.cornell.edu/facpub/1635

This Article is brought to you for free and open access by the Faculty Scholarship at Scholarship@Cornell Law: A Digital Repository. It has been accepted for inclusion in Cornell Law Faculty Publications by an authorized administrator of Scholarship@Cornell Law: A Digital Repository. For more information, please contact jmp8@cornell.edu. 


\title{
THE NEUMEIER-SCHULTZ RULES: HOW LOGICAL A "NEXT STAGE IN THE EVOLUTION OF THE LAW" AFTER BABCOCK?
}

\author{
Gary J. Simson*
}

In 1972 the New York Court of Appeals in Neumeier v. Kuehner ${ }^{1}$ significantly revised its method for deciding choice of law in cases pitting one state's negligence rule against another's guest statute. It refused to apply the interest-based approach that it had been using in tort cases since rejecting the traditional place-of-wrong rule in 1963 in Babcock v. Jackson. ${ }^{2}$ Instead, with Chief Judge Fuld-the author of the court's opinion in Babcock-writing for the majority, the Neumeier court turned to a set of three choice-of-law rules that Fuld had proposed for adoption in a concurring opinion a few years earlier. $^{3}$

Writing for the court in Neumeier, Fuld explained this departure from the Babcock approach as a response to the fact that the court's several conflicts decisions since Babcock involving guest statutes had "lacked consistency." According to Fuld, this lack of consistency could be attributed to complications inherent in the Babcock approach. It was difficult not only to ascertain the "purposes or policies underlying the relevant local law rules," but also, on occasions when "these purposes or policies are found to conflict," to decide "which should be given effect." Continued application of the Babcock approach therefore promised more inconsistency in the future.

* Professor of Law, Cornell Law School. B.A. 1971, J.D. 1974, Yale University. I thank Gregory Alexander, Rosalind Simson, and the students in my spring 1993 conflicts class for their helpful comments on a draft of this Article.

After this Article went to press, the New York Court of Appeals handed down its first decision applying the Neumeier-Schultz rules since Schultz in 1985. Cooney v. Osgood Mach., Inc., 612 N.E.2d 277 (N.Y. 1993). Cooney involved a conflict between New York and Missouri law on employer immunity from contribution claims. The Court of Appeals unanimously held that the conflict fell within the Neumeier-Schultz rules in general and Rule 2 in particular. The court did not purport to change the rules in any material respect, nor did it appear to do so implicitly. My analysis of the rules is essentially the same after Cooney as before.

1286 N.E.2d 454 (N.Y. 1972).

191 N.E.2d 279 (N.Y. 1963).

3 Tooker v. Lopez, 249 N.E.2d 394, 404 (N.Y. 1969) (Fuld, C.J., concurring).

- Neumeier, 286 N.E.2d at 457.

s Id. 
"There is, however," Fuld asserted with a confidence reminiscent of his opinion for the court in Babcock, "no reason why choice-of-law rules, more narrow than those previously devised, should not be successfully developed, in order to assure a greater degree of predictability and uniformity, on the basis of our present knowledge and experience." Babcock and subsequent guest-statute conflicts cases decided by the New York high court would facilitate the task of developing rules for conflicts cases involving guest statutes because "they have helped us uncover the underlying values and policies which are operative in this area of the law." Indeed, "Now that these values and policies have been revealed,' "wrote Fuld (quoting from his earlier concurring opinion), "we may proceed to the next stage in the evolution of the law-the formulation of a few rules of general applicability, promising a fair level of predictability." ",

In 1985 the New York Court of Appeals in Schultz v. Boy Scouts of America $^{9}$ expanded both the Neumeier rules and their range of applicability. The court essentially added a fourth rule in the form of a public policy exception. Furthermore, although the Neumeier rules are phrased in terms that focus specifically and exclusively on conflicts between a negligence standard and a guest statute, the court in Schultz held that the rules could readily and sensibly be applied to a wide range of other tort choice-of-law problems.

As my contribution to this symposium commemorating Babcock, I consider whether the rules that emerge from Neumeier and Schultz meet the Neumeier court's promise of a genuine step forward from Babcock. After setting out the Neumeier-Schultz rules, I analyze them from two perspectives. First, how well do they lend themselves to consistent application? Second, how well do they implement other important choice-of-law objectives? I conclude by suggesting a choice-of-law approach that I believe responds more successfully to the Neumeier court's concern for consistency in decisionmaking while also serving more fully other important choice-of-law objectives.

\footnotetext{
${ }^{a}$ Id.

Id.

s Id. (quoting Tooker v. Lopez, 249 N.E.2d 394, 408 (N.Y. 1969) (Fuld, C.J., concurring)). For a variety of perspectives on Neumeier not long after it was handed down, see Symposium, Neumeier v. Kuehner: A Conflicts Conflict, 1 Hofstra L. Rev. 93 (1973).

• 480 N.E.2d 679 (N.Y. 1985).
} 


\section{The Neumeier-SChultz RULes}

The three rules adopted for guest-statute cases by the Neumeier court were as follows:

1. When the guest-passenger and the host-driver are domiciled in the same state, and the car is there registered, the law of that state should control and determine the standard of care which the host owes to his guest.

2. When the driver's conduct occurred in the state of his domicile and that state does not cast him in liability for that conduct, he should not be held liable by reason of the fact that liability would be imposed upon him under the tort law of the state of the victim's domicile. Conversely, when the guest was injured in the state of his own domicile and its law permits recovery, the driver who has come into that state should not-in the absence of special circumstances-be permitted to interpose the law of his state as a defense.

3 . In other situations, when the passenger and the driver are domiciled in different states, the rule is necessarily less categorical. Normally, the applicable rule of decision will be that of the state where the accident occurred but not if it can be shown that displacing that normally applicable rule will advance the relevant substantive law purposes without impairing the smooth working of the multistate system or producing great uncertainty for litigants. ${ }^{10}$

The Schultz court recognized, as essentially a fourth rule, a public policy exception to the operation of the above rules. According to the court in Schultz, if application of the above rules calls for a choice of nonforum law, a court should not always apply the indicated law. Rather, it should refuse to do so when both of two conditions are met: (1) the nonforum law is contrary to New York's "fundamental public policy"; and (2) there are "enough important contacts between the parties, the occurrence and the New York forum to implicate [New York] public policy and thus preclude enforcement of the foreign law."11

The Schultz court also established that the rules set forth in Neumeier are not limited in applicability to guest-statute problems. In the course of holding the rules applicable to resolve a conflict between laws pertaining to charitable immunity for negligent hiring

\footnotetext{
10 Neumeier, 286 N.E.2d at 457.58.

1 Schultz, 480 N.E.2d at 688.
} 
and supervision, the court brought within the scope of the rules any tort issue where the laws in conflict are "loss-allocating rather than conduct-regulating." 12 "Loss-allocating" laws were said to include ones such as "those limiting damages in wrongful death actions, vicarious liability rules, or immunities from suit."13

\section{Promise of Consistent Application}

Since the Neumeier court expressly defended its creation of new choice-of-law rules as a means of remedying inconsistent decisionmaking in choice of law, the least that could be expected of the Neumeier-Schultz rules is that they would promise to have a high degree of consistency in application. For a number of reasons, however, it is doubtful that they promise anything of the sort.

Consider, for example, the provision for "special circumstances" in Rule 2. ${ }^{14}$ According to Rule 2, "special circumstances" may justify choosing the guest statute of a driver's home state over the negligence standard of the state where the guest is domiciled and suffered injury. Neither the rule nor the Court of Appeals' opinions in Neumeier and Schultz, however, offer any guidance as to what circumstances might or might not count as "special." Unless and until the high court provides such guidance, this "special circumstances" exception plainly invites widely variable application.

The provision in Rule 3 for "displacing" the law of the place of accident if doing so would "advance the relevant substantive law pur-

12 Id. at 686.

${ }^{13}$ Id. at 685. My focus in this Article is the validity of the Neumeier-Schultz rules, not how well or poorly the New York courts have applied them. The New York Court of Appeals' application of the rules in Schultz, however, seems so strained in behalf of such an unappealing result that I probably should at least note my puzzlement with the decision. In light of the importance assigned by the rules to the place of the tort, see infra text accompanying notes 36 , 48 , it was no mean feat for the court to conclude that the nonimmunity law of New York, the place of the tort, applied to neither of the two charitable corporate defendants in the case. In essence, one defendant was rescued from New York law by a holding in the teeth of Miller v. Miller, 237 N.E.2d 877 (N.Y. 1968), that the defendant's post-tort change of domicile was of no account; the other defendant was saved from New York law by a dubious determination that the analysis of state interests mandated by Rule 3, see infra text accompanying notes 15-17, required displacement of the law of the place of tort. The choice of law achieved by this apparent straining was one that the court might have been expected to bend over backwards to avoid: New Jersey's charitable immunity law applied, with the result that the plaintiffs could not recover for the charities' alleged negligence in hiring and supervising an employee who, according to the complaint, repeatedly sexually molested the plaintiffs' two children, driving one to suicide and leaving the other severely psychologically and emotionally scarred.

14 Neumeier, 286 N.E.2d at 458. 
poses"15 also poses an obvious threat to consistent decisionmaking. Moreover, the threat posed by this provision cannot arguably be countered simply by judicial clarification of terminology. It arises not out of vagueness or ambiguity in the wording of the rules, but rather out of the methodology that the provision invokes. As the Court of Appeals' opinions in Neumeier and Schultz make clear, ${ }^{16}$ this part of Rule 3 calls for a $B a b c o c k$-style analysis of state interests. Subject to two exceptions, it mandates the displacement of the law of the state of accident if that state's (A's) interest in the application of its (A's) relevant local law to the facts of the particular case is less than the interest of another state (B) in the application of its (B's) relevant local law to the case. If, as the Neumeier court itself maintained, ${ }^{17}$ complications inherent in the Babcock approach substantially contribute to inconsistent decisionmaking, it seems apparent that making the approach a central ingredient of Rule 3 cannot help but materially limit that rule's promise of consistent application.

The likelihood of consistent decisionmaking is also materially undercut by one of the two exceptions to the above provision for displacing the law of the place of accident. ${ }^{18}$ According to Rule 3 , even though an analysis of state interests indicates that the law of the place of accident should be displaced, there should be no such displacement if it would have the effect of "impairing the smooth working of the multistate system."18 The quoted exception reflects concern for a choice-of-law policy that the Restatement (Second) of Conflict of Laws and various commentators have affirmed as central to choice of law: serving the needs of the interstate and international systems. ${ }^{20}$ The exception implements this important policy in a way, however, that significantly invites inconsistent application. Rather than specifying the types of impairments of the multistate system that choice-of-law decisions threaten to cause, the exception simply

\footnotetext{
${ }^{18}$ Id.

16 See Schultz, 480 N.E.2d at 687 ; Neumeier, 286 N.E.2d at 458.

17 See Neumeier, 286 N.E.2d at 457.

1s It is also undercut by the other exception-that based on "producing great uncertainty for litigants," see Neumeier, 286 N.E.2d at 458 -but, as a result of that exception's substantially sharper and narrower focus, probably not materially so.

18 Neumeier, 286 N.E.2d at 458.

${ }^{20}$ See, e.g., Restatement (Second) of Conflict of Laws § 6(2)(a) \& cmt. d (1969); Elliott E. Cheatham \& Willis L.M. Reese, Choice of the Applicable Law, 52 Colum. L. Rev. 959, 962 64 (1952); Robert A. Leflar, Choice-Influencing Considerations in Conflicts Law, 41 N.Y.U. L. Rev. 267, 285-87 (1966); Gary J. Simson, Plotting the Next "Revolution" in Choice of Law: $A$ Proposed Approach, 24 CoRnell INT'L L.J. 279, 293-94 (1991).
} 
refers broadly to such impairments. ${ }^{21}$ Probably even more importantly, the exception is not limited in scope to instances of very tangible impairment.

The public policy exception that the Schultz court recognized as relevant to all three rules also militates significantly against consistency in choice of law. Part of the problem lies in its requirement that, for an otherwise applicable foreign law to be refused application, such law must be contrary to the forum's "fundamental" public policy. ${ }^{22}$ Though hardly novel in New York-and, indeed, partly because of its long history of variable interpretation in New York $^{23}$ - this requirement is sufficiently imprecise to invite substantial inconsistency in application.

The principal problem with the public policy exception, however, as far as consistent decisionmaking in choice of law is concerned, lies in its additional requirement that there be "enough important contacts between the parties, the occurrence and the New York forum to implicate [New York] public policy and thus preclude enforcement of the foreign law." ${ }^{24}$ What criteria should be used to decide whether particular forum contacts are "important" and whether there are "enough" important contacts? The little illumination that the Schultz court shed on this obvious question was offered in the course of a discussion of three prior cases-all pre-Babcock-in which the New York high court had refused to apply foreign law based on the public policy doctrine. ${ }^{25}$ The discussion is amenable to a number of quite different interpretations as to when "enough important contacts" exist. Among them: a New York interest in applying forum law is necessary and sufficient; a New York interest in applying forum law is necessary, but it is not sufficient in the absence of a substantial connection between both parties and New York; and a New York interest is not necessary, nor is it sufficient in the absence of a substantial connection between both parties and New York. Perhaps in a future case the Court of Appeals will clarify its requirement of "enough important contacts." As should be apparent, however, any

31 Although the court in both Neumeier and Schultz indicated that choice-of-law decisions that encourage forum shopping can impair the smooth working of the multistate system, see Schultz, 480 N.E.2d at 687; Neumeier, 286 N.E.2d at 458 , it did not establish that encouragement of forum shopping exhausts (for purposes of the exception) the types of impairments of the multistate system that choice-of-law decisions threaten to cause.

22 Schultz, 480 N.E.2d at 688.

${ }^{23}$ See, e.g., Intercontinental Hotels Corp. v. Golden, 203 N.E.2d 210 (N.Y. 1964); Mertz v. Mertz, 3 N.E.2d 597 (N.Y. 1936); Loucks v. Standard Oil Co., 120 N.E. 198 (N.Y. 1918).

${ }^{24}$ Schultz, 480 N.E.2d at 688.

${ }^{25}$ Id. 
clarification that assigns significance to the existence of a New York interest has the potential for inconsistency that the Neumeier court perceived in any application of the Babcock approach. ${ }^{26}$

Finally, in extending the applicability of the rules in Neumeier beyond the guest-statute context that they expressly address, the Schultz court adopted a criterion for applicability that stands as yet another formidable obstacle to consistent decisionmaking in choice of law. According to the court in Schultz, the rules apply only when the laws in conflict as to the "particular tort issue" at hand are "lossallocating rather than conduct-regulating." ${ }^{27}$ This criterion contributes substantially to inconsistency in ultimate choice-of-law decisions by inviting inconsistency in the preliminary decision of whether a choice-of-law issue is governed by the rules or instead should be decided by the otherwise applicable approach. It invites inconsistency in this threshold determination by requiring courts to resolve two characterization questions that frequently resist logical resolution. First, as is commonly suggested in the course of discussions of the manipulability of the traditional territorial rules, it is often unclear whether an issue should be characterized as one in tort or, instead, as one in perhaps contract or property, because the issue implicates elements of more than one area of law. ${ }^{28}$ Second, as the conflicting laws in Schultz itself illustrate, the correct answer to the question whether the laws in conflict are loss-allocating or conduct-regulating is often that they are not one or the other but both. While the New Jersey law in Schultz immunizing charities from liability for negligent hiring and supervision may fairly be characterized as loss-allocating, the same cannot be said of the contrary New York law involved in the case. As the lone dissenter in Schultz rightly pointed out, an important and perhaps dominant purpose behind many laws denying tort immunity is to influence behavior, and there was every reason to find that such a purpose lay behind the New York law. ${ }^{28}$ Although a lossallocating purpose can also be fairly attributed to the New York law, the conflicting laws cannot properly be described as "loss-allocating rather than conduct-regulating" because, the majority in Schultz notwithstanding, they are both.

\footnotetext{
${ }^{28}$ Neumeier, 286 N.E.2d at 457.

${ }^{27}$ Schultz, 480 N.E.2d at 684-86.

28 See, e.g., Robert A. Leflar et al., American Conflicts Law $\S 87$ (4th ed. 1986); Joseph Morse, Characterization: Shadow or Substance, 49 Colum. L. REv. 1027 (1949).

${ }^{20}$ See Schultz, 480 N.E.2d at 691-92 (Jasen, J., dissenting). See generally James A. Henderson, Jr. \& Richard N. Pearson, The Torts Process 38-42 (3d ed. 1988) (discussing the purposes commonly served by imposing tort liability).
} 


\section{Attention to Other Choice-óf-Law Policies}

Thus far I have tried to show that the Neumeier-Schultz rules are materially deficient in terms of achieving consistency in choice of law-the policy that the Neumeier court cited as its basis for departing from the Babcock approach in favor of rules. I turn now to the rules' adequacy in terms of other policies deserving of serious consideration in a system of choice of law.

Rule 1 requires application of the law of the state of common domicile and assigns no importance to the place of the tort. ${ }^{30}$ In doing so, it rather obviously seeks to duplicate the results of interest analysis in a Babcock-like situation. In essence, it treats such a situation as a "false conflict" 31 and provides for a choice of the law of the only interested state. In policy terms, the rule gives priority to maximizing long-term enforcement of forum-state interests-the policy basis for the interest-analysis approach. ${ }^{32}$ Moreover, the rule purports to give priority to this policy by adhering to a strategy-in false conflicts, apply the law of the interested state-that proponents of interest analysis have hailed as strategically sound..$^{33}$ In Part IV, I will question whether interest analysis as formulated by Currie and as generally understood by courts and commentators today is a good vehicle for maximizing long-term enforcement of forum interests. For present purposes, however, I assume that it is and analyze from that perspective the validity of the rules insofar as they rely implicitly upon interest analysis.

One shortcoming of Rule 1 is that it often treats as "false" a conflict that is better understood as "true." The rule tacitly assumes that the common-domicile cases that it covers involve only one interested state. Some such cases, however, simply do not fit the mold; and in such "true-conflict" cases, the policy of maximizing long-term en-

\footnotetext{
so Neumeier, 286 N.E.2d at 457.

s1 For Brainerd Currie's seminal discussion of "false" and "true" conflicts, see Brainerd Currie, Selected Essays on the Conflict of Laws ch. 2 (1963) [hereinafter Currie, Selected Essays] (reprinting Brainerd Currie, Married Women's Contracts: A Study in Conflict-of-Laws Method, 25 U. CHI. L. Rev. 227 (1958)).

${ }^{32}$ See Gary J. Simson, Issues and Perspectives in Conflict of Laws: Cases and Materials 87 (2d ed. 1991); Gregory S. Alexander, The Concept of Function and the Basis of Regulatory Interests Under the Functional Choice-of-Law Theory: The Significance of Benefit and the Insignificance of Intention, 65 VA. L. REv. 1063, 1079-80, 1091 (1979); William F. Baxter, Choice of Law and the Federal System, 16 Stan. L. Rev. 1, 6-8 (1963); Larry Kramer, Rethinking Choice of Law, 90 Colum. L. Rev. 277, 311-16 (1990). Although Brainerd Currie may not have expressly subscribed to this understanding of the policy basis for the approach, he did so implicitly. See Simson, supra note 20, at 295 n.44.

${ }^{33}$ See, e.g., Currie, Selected Essays, supra note 31, at 183-84; Baxter, supra note 32, at 6-8.
} 
forcement of forum-state interests seems to call for a more complex strategy than the rule's mandate of uniform application of the law of the state of common domicile. The rule's false-conflict assumption may work fairly well in guest-statute cases because, in light of the numerous deterrents to unsafe driving even if drivers cannot be sued for negligence by guests, it is dubious that a state's adoption of, or adherence to, a nonimmunity law in this context is substantially motivated by a conduct-regulating purpose. As already discussed with reference to the laws in Schultz, ${ }^{34}$ however, many nonimmunity laws may reasonably be found to reflect a conduct-regulating purpose in substantial part. Moreover, the same may be said of many laws imposing vicarious liability or placing no ceiling on wrongful-death damages-two other types of laws that the Schultz court specifically indicated were covered by the rules..$^{35}$ Under the interest-analysis approach, a court could sensibly decide that if the tortious conduct occurred in a state with a nonimmunity (or vicarious liability or unlimited damages) law having a substantial conduct-regulating purpose, that state has an interest in the application of its law despite the parties' common domicile outside the state.

A second difficulty with Rule 1 is that it implicitly bars consideration of any choice-of-law policy other than maximizing long-term enforcement of forum interests. The fact that the parties have a common domicile in a particular state does not preclude the possibility that policies such as protecting justified expectations and serving the needs of the interstate and international systems may militate strongly in favor of a choice of the law of another state. Yet, Rule 1 allows courts no leeway to take these policies into account. To the extent that this may not appear to be a serious objection in the guest-statute context, it is again important to keep in mind the broad range of applicability that the Schultz court gave to the rules.

Rule 2 generally calls for application of the law of the place of tort in divided-domicile cases in which the tort occurred in one of the two domiciliary states and each party would be favored by application of his or her home-state law. The rule allows for a choice of the law of the domiciliary state where the tort did not occur only when "special circumstances" support such a choice and the tort occurred in the guest's home state. Putting aside this exception for the moment, the thinking behind the rule seems fairly apparent: the situations cov-

\footnotetext{
34 See supra text accompanying note 29.

so Schultz, 480 N.E.2d at 685 .
} 
ered are "true conflicts";" since interest analysis does not yield a clear answer, the sensible thing to do is to revert back to the traditional tort rule.

So understood, Rule 2 is open to an array of objections with important policy implications. First, there is good reason to believe that Rule 2 treats some conflicts as "true" that are better understood as "false." If so, then Rule 2 wrongly treats interest analysis as inconclusive in various cases in which it plainly is not, thus making the rule less than ideal as a means of maximizing long-term enforcement of forum interests. The possibility that Rule 2 embraces some falseconflict cases may seem remote if one focuses exclusively on gueststatute cases. This possibility begins to seem quite real, however, if one looks instead at the entire range of tort cases that, courtesy of Schultz, are encompassed by the rules. In particular, it is no longer so obvious that a law whose application would favor the tort plaintiff was adopted substantially for the purpose of benefiting such plaintiffs. It may have been adopted exclusively or almost exclusively for such other purposes as deterring a certain class of possible defendants from engaging in certain undesirable behavior or making a certain class of possible defendants act in a more socially responsible way for their own good. Whether or not the lawmaker may have been somewhat wrongheaded to adopt the law exclusively or almost exclusively for these other purposes is beside the point. ${ }^{37}$ The relevant concern under interest analysis is actual legislative purposes.

Second, even if one assumes that Rule 2 encompasses nothing but true conflicts, the rule is seriously flawed as a means of maximizing long-term enforcement of forum interests. The rule's tacit premise that interest analysis is inconclusive in true-conflict cases is simply wrong. The fact that there is more than one interested state does not somehow render unusable the policy informing interest analysis of maximizing long-term enforcement of forum interests. A perfectly sensible strategy-not necessarily the only sensible strategy, though probably the most sensible one-for implementing this policy in true-conflict cases is to apply the law of the most interested state and, in cases of "ties" between the forum state and another state for

${ }^{36}$ See supra note 31.

${ }^{37}$ See, e.g., Cipolla v. Shaposka, 267 A.2d 854, 858 (Pa. 1970) (Roberts, J., dissenting) ("Of course a statute could be passed for a particular purpose, even though it is poorly designed to effectuate that purpose. But I do not believe that is the case here, for neither the Legislature nor the courts of Delaware have ever mentioned low insurance rates as the purpose of the guest statute."). Cf. CURrie, Selected Essays, supra note 31, at $85 \&$ n.17 (discussing policy behind laws limiting married women's contractual capacity); $i d$. at 377 (discussing legislative history). 
the greatest interest, to vindicate the forum interest. ${ }^{38}$ This strategy is predicated on notions of reciprocity ${ }^{39}$ and reflects a reasonable judgment as to whether, in light of the relative magnitude of the conflicting interests, the policy of maximizing long-term enforcement of forum interests is best served by (1) enforcing the nonforum interest and thereby encouraging reciprocal treatment from other states' courts or (2) enforcing the forum interest and thereby passing up any advantages that might accrue from trying to stimulate reciprocity.

Third, if a court is going to stop pursuing the policy of maximizing long-term enforcement of forum interests, it could hardly do worse in a policy sense than revert back to the place-of-wrong rule-the course of action prescribed by Rule 2. The old rule is so lacking in rational justification as to approach, if not surpass, constitutional bounds. ${ }^{40}$ Though defended as a means of simplifying the judicial task and ensuring uniformity of result, the place-of-wrong rule does not serve these policies particularly well. (Compare a rule of applying the law of the contact state first in alphabetical order. ${ }^{41}$ ) Moreover, it is dubious that these policies provide an adequate foundation for a rational system of choice of law. (Think again about having an alphabetical-order rule.) To the extent that defenders of the place-ofwrong rule rely on its nexus to protecting justified expectations, they succeed in identifying a policy upon which a rational system of choice of law conceivably might be built. ${ }^{42}$ They are notably less successful, however, in demonstrating that the nexus between the place-ofwrong rule and this policy has any real substance.

Fourth, the reversion prescribed by Rule 2 to the place-of-wrong rule seems to be based on some notion that the old rule is the natural fallback if modern methods of choice of law are inconclusive. This thinking not only gives too much importance to the place-of-wrong rule; it also gives too little importance to forum law and to the policies that always lend support to a choice of forum law. ${ }^{43}$ Forum law is

\footnotetext{
38 See Simson, supra note 20, at 280-82. Cf. CuRrIe, Selected Essays, supra note 31, at 119 ("The sensible and clearly constitutional thing for any court to do, confronted with a true conflict of interests, is to apply its own law. In this way it can be sure at least that it is consistently advancing the policy of its own state.").

39 See generally Robert M. Axelrod, The Evolútion of Cooperation (1984).

10 See Simson, supra note 32, at 14-15, 355; Gary J. Simson, State Autonomy in Choice of Law: A Suggested Approach, 52 S. CAL. L. Rev. 61, 83 (1978) [hereinafter Simson, State Autonomy].

4T The notion of an alphabetical-order rule apparently originates with Currie, who proposed it "[i]n all solemnity" for certain types of cases. See Currie. Selected Essays, supra note 31, at 609 .

42 For detailed examination of this policy, see Simson, supra note 32, at ch. 4.

43 See id. at ch. 1 ("Why Not Always Apply Forum Law?").
} 
the law most readily accessible and familiar to the court-the law that the court can find with the smallest expenditure of time and effort and that the court is least likely to misapply. ${ }^{44}$ Forum law is also the law that reflects the forum state's considered judgment as to what, in general, is the fairest or most socially beneficial way of ordering people's interests when such interests collide. ${ }^{45}$ As a body elected by the people of the forum state or appointed by elected forum-state officials to serve the best interests of the people of the state, a state court has a special obligation to take this collective judgment into account. In short, if a court determines that its modern methods of analysis do not provide relatively strong reasons for applying foreign law, the reasons that always militate in favor of a choice of forum law should be decisive. Indeed, as discussed further in Part IV, ${ }^{46}$ these reasons are sufficiently weighty that forum law is probably best seen not as merely a natural fallback but, instead, as a natural point from which to begin.

Fifth, Rule 2, like Rule 1, leaves no room for courts to take into account that such important choice-of-law policies as serving the needs of the interstate and international systems and protecting justified expectations may militate strongly in favor of a particular choice of law. The needs of the interstate and international systems are completely outside the purview of Rule 2 . The protection of justified expectations figures in Rule 2 only insofar as it is tacitly served by the required reference to the place-of-wrong rule, and as indicated above, ${ }^{47}$ there is no reason to suppose that it is tacitly served by this reference at all well.

Lastly, the "special circumstances" exception to Rule 2 biases the rule in favor of defendants for no apparent reason. Though extremely vague, the exception plainly does have the effect of allowing defendants covered by the rule a valuable opportunity that plaintiffs covered by the rule are denied: the opportunity to avoid application of the law of the place of the wrong when they would prefer that another law apply. Neither Rule 2 nor the New York high court's opinions to date offer any justification for the onesidedness of this excep-

\footnotetext{
“4 See Allstate Ins. Co. v. Hague, 449 U.S. 302, 326 \& n.14 (1981) (Stevens, J., concurring); Amos Shapira, "Manna for the Entire World" or "Thou Shalt Love Thy Neighbor As Thyself"-Comment on Neumeier v. Kuehner, 1 Horstra L. Rev. 168, 171 (1973); Leflar, supra note 20 , at 288 .

4s See Albert A. Ehrenzweig, The Lex Fori-Basic Rule in the Conflict of Laws, 58 Mich. L. REv. 637, 637-41 (1960); Shapira, supra note 44, at 171-72; Simson, supra note 20, at 289-90; Joseph W. Singer, Facing Real Conflicts, 24 CoRNELL INT'L L.J. 197, 201 (1991).

to See infra text accompanying note 64.

${ }^{47}$ See supra text accompanying note 42.
} 
tion, thereby leaving the exception and the rule of which it is a part open to attack for arbitrariness. In response to such a charge it perhaps might be argued that this onesidedness is defensible as simply an expression of policy by New York that it is more important to protect tort defendants from liability than tort plaintiffs from loss. However, if the Neumeier court in adopting the exception intended it to express such a New York policy, the exception seems anomalous in cases where the New York law at issue gives priority to protecting plaintiffs from loss. In short, if this exception is not simply arbitrary in its onesidedness, its policy basis is often incompatible with the policy preference reflected by the New York tort law claimed to apply in the case.

Rule 3 covers all divided-domicile cases not covered by Rule 2. It establishes a presumption in favor of the law of the place of the tort that can be rebutted only by a showing that (1) an analysis of state interests favors an alternative choice of law and (2) such alternative choice of law would neither impair the smooth working of the multistate system nor produce great uncertainty for litigants. Though not expressly indicated, the type of situation that Rule 3 seems to take as "normal"48 is one represented by the configuration of facts and laws in Neumeier itself: the tort occurred in one of the two domiciliary states, and each party would be disfavored by application of his or her home-state law. As the Neumeier court explained," the "normally applicable rule" under Rule 3 of applying the law of the place of wrong governs in such situations because interest analysis does not suggest otherwise. Moreover, apparently in the court's view, interest analysis does not suggest otherwise because in such situations neither of the two states involved has an interest.

Rule 3 presents two difficulties that should require little discussion because similar difficulties have been discussed with relation to Rule 2. First, even a rebuttable presumption that the place-of-wrong rule applies gives far more deference to that traditional rule than it deserves. ${ }^{30}$ Second, any notion of the place-of-wrong rule as a natural fallback when modern methods are inconclusive is misguided not only because it embraces a rule not worth embracing but also because it fails to recognize the advantages that always accompany a choice of forum law. ${ }^{51}$

48 Neumeier, 286 N.E.2d at 458 (text of Rule 3, which twice uses the term "normally").

49 Id.

so See supra text accompanying notes $40-42$.

st See supra text accompanying notes 43-46. 
Unlike Rules 1 and 2, Rule 3 cannot be criticized for precluding express consideration of the impact of possible choices of law on the multistate system and the parties' expectations. It can be criticized, however, for the ways in which it structures and limits judicial inquiry into such matters. Thus, for example, Rule 3 allows courts to consider only whether displacement of the place-of-wrong rule would have an adverse impact on the multistate system or party expectations. It gives them no authority to consider whether a choice of the law of the place of wrong would have such an adverse impact. Another problem is that Rule 3 assigns greater significance to adverse impacts on the multistate system than such impacts appear to deserve. Neither the rule on its face nor any discussion of it by the New York high court to date indicates that such an impact needs to be at all substantial in order to defeat the choice of law suggested by an analysis of state interests. Even if a court reasonably may give priority to serving the needs of the multistate system over maximizing long-term enforcement of forum interests, it does not follow that this latter policy sensibly should give way when the former is not materially implicated. Yet, implicitly, this is precisely what Rule 3 demands.

The public policy exception recognized in Schultz probably compensates to some extent for certain shortcomings of the rules. By vindicating forum law when the rules point elsewhere, the exception may operate to counter the rules' inadequate attention to forum interests and the natural advantages of applying forum law. Particularly in light of its vague contours, ${ }^{52}$ however, there is no reason to suppose that this exception remedies these deficiencies to any great degree. Indeed, it would seem nothing short of miraculous if this somewhat spruced-up remnant of the traditional methodology could simply be tossed into the mix and these basic deficiencies in the rules would largely disappear.

\section{An Alternative "Next Stage"}

In my view the analysis in Parts II and III virtually compels the conclusion that the Neumeier-Schultz rules are a failure. Moreover, although this analysis of the New York rules by no means compels the conclusion that the general enterprise of judicial rulemaking in choice of law is doomed to failure, it hardly provides encouragement in this regard. Even if limited in application to the guest-statute con-

32 See supra text accompanying notes 22-26. 
text that they expressly address, the rules have serious deficiencies; and these deficiencies bode ill for rulemaking generally, because the rules were the product of considerable experience with guest-statute cases on the part of the rulemaking court. Very simply, if these are the kind of rules that courts formulate when they are well-versed in a particular area, there is much reason for trepidation when they formulate rules in areas in which their background is relatively meager. By the same token, the difficulties created by the Schultz court's expansion of the rules' range of applicability suggest that there may well be no reliable shortcuts to a system in which choice of law is broadly and soundly governed by rules. From this perspective, the task of devising such a system appears to be highly onerous at best.

Perhaps courts, either on their own or with the aid of published proposals by conflicts scholars, are capable of doing far better than the Neumeier-Schultz rules. Or perhaps the answer is to look to legislatures to take on in earnest the task of rulemaking in choice of law. I am skeptical in both regards, but for present purposes I do not press my doubts. ${ }^{53}$ Instead, I suggest an alternative means of accomplishing what such rules optimally would achieve. I describe below an approach that I believe would facilitate a high degree of consistency in decisionmaking while accommodating well other important choiceof-law policies. Because I described both this approach and its logical underpinnings in some detail when I first proposed it in an article in $1991,{ }^{\text {,4 }}$ I present only its basic outlines here and refer the reader to the 1991 article for a more complete account.

My approach consists of three steps that may be summarized as follows:

1. Ascertain whether any state has a greater interest in determining the outcome of the case at hand than the forum state.

2. If so, make the choice(s) of law that a court sitting in the foreign state and applying that state's conflicts law would make.

3. If not, apply forum law with regard to each issue in the case unless:

\footnotetext{
s3 For a sampling of the extensive debate among conflicts scholars as to the wisdom of trying to devise new choice-of-law rules, see Willis L.M. Reese, Choice of Law: Rules or Approach, 57 CoRnell L. Rev. 315 (1972); Robert A. Sedler, The Governmental Interest Approach to Choice of Law: An Analysis and a Reformulation, 25 UCLA L. REv. 181, 208-16 (1977); Joseph W. Singer, Real Conflicts, 69 B.U. L. REv. 1, 6-23 (1989).

s4 Simson, supra note 20.
} 
a. The foreign elements in the case bring into play a policy that would not be materially implicated if the case were confined in its elements to the forum state;

b. Such policy militates strongly in favor of a choice of nonforum law; and

c. The policy preference expressed in the forum state's internal law is not so strong as to belie the possibility that the forum state's lawmakers could intend it to yield to another policy in a multistate case. ${ }^{\mathbf{5 s}}$

Broadly speaking, Step 1 directs a court to make a choice of jurisdiction: identify the jurisdiction that should have authority to determine the outcome of the case before the court. Steps 2 and 3 tell the court how to give effect to its decision as to which jurisdiction should have authority to determine the outcome of the case: apply the selected jurisdiction's choice-of-law methodology from the perspective of a court sitting in that jurisdiction.

More specifically, Step 1 seeks to serve the policy of maximizing long-term enforcement of the forum state's interests by a strategy that I defended above in criticizing Rule 2: vindicate the forum-state interest unless another state has a greater interest. ${ }^{56}$ In addition, Step 1 defines the relevant state interests quite differently than proponents of interest analysis ordinarily do. Brainerd Currie and the many courts and commentators who have drawn on his work focus on states' interests in applying the policies underlying their internal laws; ${ }^{\mathbf{5 7}}$ and the Currie approach decides the existence of a state interest by whether application of an underlying policy would in some way benefit the residents of the lawmaking state. ${ }^{58}$ By contrast, Step 1 focuses on states' interests in determining the outcome of the case;

so Id. at 279 .

so See supra text accompanying notes 38-39. Step 1 proceeds within the framework of the Supreme Court's current understanding that the Full Faith and Credit Clause, see U.S. Const. art. IV, $\S 1$, is not a significant constraint on state prerogatives in choice of law. See Simson, supra note 20, at 288 n.18; Louise Weinberg, Against Comity, 80 Geo. L.J. 53, 68 (1991). A number of years ago I argued for a strong conception of full faith and credit constraints-one requiring uniformity among the 50 states in the laws that their courts would apply to decide any particular case. See Simson, State Autonomy, supra note 40, at 66-69. If the Court adopted this conception, the approach proposed in my 1991 article would have to be revised to provide that in all cases of "ties"-even ones involving the forum state-there would be two selected jurisdictions. For discussion of how to go about respecting the decisionmaking authority of two jurisdictions, see id. at 75-76; Simson, supra note 20, at 289; infra note 63.

${ }^{\circ 7}$ See, e.g., Babcock v. Jackson, 191 N.E.2d 279 (N.Y. 1963); CurRIE, Selected Essays, supra note 31, at 183-84; Sedler, supra note 53, at 222-27.

- See Currie, Selected Essays, supra note 31, at 85-87; Sedler, supra note 53, at 183-86. 
and as explained in the 1991 article, ${ }^{58}$ it decides the existence of a state interest by whether the outcome will affect the welfare of the state's residents.

In brief, I suggest that my definition of the relevant state interests is preferable to the Currie definition in two regards. First, it captures much more effectively the full range of state interests that actually are implicated in conflicts cases. It tacitly takes into account not only states' interests in applying their own internal laws but also their interests in applying (for purposes of protecting justified expectations or serving another choice-of-law policy) other states' internal laws. Similarly, it implicitly encompasses not only states' interests in applying their internal laws to benefit local residents but also their interests in applying these laws to disadvantage local residents in behalf of the local sense of fairness and morality.

Second, my definition of the relevant state interests makes the judicial task considerably more manageable and concrete than it is under the Currie approach. At a minimum the Currie approach requires an inquiry into the policy or policies that actually motivated adoption of a law. According to some proponents of the Currie approach, it also requires an inquiry into whether the lawmaking state would regard a policy as applicable under the facts of the case. ${ }^{60} \mathrm{By}$ contrast, my approach to state interests forgoes any inquiry into the thought processes of the state. It requires instead an objective inquiry into the effect of the outcome on the residents of the states connected with the case. Although this latter inquiry at times may be complex, a strong argument can be made for limiting the court's focus to the potential impact of the outcome on the parties before the court. ${ }^{61}$ If this simplification is adopted, a court can identify the selected jurisdiction under Step 1 solely on the basis of the parties' states of residence: if the plaintiff and the defendant ${ }^{62}$ reside in the same state, that state is the selected jurisdiction; if they reside in different states one of which is the forum, the forum state is the selected jurisdiction; and if they reside in different states neither of which is the forum, both foreign states are selected jurisdictions-a

\footnotetext{
68 Simson, supra note 20 , at 282.

${ }^{60}$ For discussion of the debate among interest analysts as to whether this second inquiry is required, see Larry Kramer, More Notes on Methods and Objectives in the Conflict of Laws, 24 CORnell InT'L L.J. 245, 265 (1991).

61 See Simson, supra note 20, at 284-87.

62 In a case with more than two parties, my approach needs to be applied to one plaintiff and one defendant at a time. See id. at 284 n.14.
} 
situation that makes the ultimate choice of law more complicated than usual but not unmanageable. ${ }^{\theta 3}$

Step 2 prescribes the approach that a court should follow when it determines that a foreign state is the selected jurisdiction. Out of respect for the foreign state's paramount claim to decisionmaking authority, Step 2 takes as a given the foreign state's choice-of-law methodology. The court decides the case as the foreign state would decide it by applying the foreign state's choice-of-law methodology as if it were sitting in that state.

A presumption in favor of forum law lies at the heart of Step 3. As discussed above in my critique of Rule $2,{ }^{64}$ a choice of forum law always has a certain logic to it in terms of simplifying the judicial task and serving the forum state's sense of justice. Step 3 proceeds on the view that these natural advantages of applying forum law are sufficiently great to justify making forum law not only the court's initial focal point but also, absent strong reasons for departing from forum law, its final destination.

The three conditions specified in Step 3 as legitimating nonapplication of forum law acknowledge the possibility that the policy balance reflected by forum law may not be the balance that the forum state would strike for a case including some out-of-state elements. The out-of-state elements may implicate a policy that would not be materially implicated if the case were entirely intrastate. If one assumes that in formulating local law the lawmakers of the forum state acted with intrastate cases foremost in mind-an assumption that seems reasonable and that Currie and others regularly have made $^{65}$ - then this policy presumably did not figure significantly in the formulation of forum law. If such a policy strongly supports a choice of nonforum law in a particular case, and if the policy prefer-

\footnotetext{
*s As discussed in the 1991 article, see id. at 289 , the court in this situation must consult the conflicts law of each selected foreign jurisdiction to ascertain the choice of law that a court sitting in that foreign state would make. If courts sitting in each of the two foreign states would make the same choice of law, the court plainly should opt for that choice of law. If they would make different choices of law, the court should try to decide the case in a way that gives equal respect to each selected foreign jurisdiction's interest in determining the outcome. Methods proposed by commentators for giving equal respect to conflicting Currie-style state interests offer means for doing so. See, e.g., Aaron D. Twerski \& Renee G. Mayer, Toward a Pragmatic Solution of Choice-of-Law Problems-At the Interface of Substance and Procedure, 74 Nw. U. L: Rev. 781 (1979); Arthur T. von Mehren, Special Substantive Rules for Multistate Problems: Their Role and Significance in Contemporary Choice of Law Methodology, 88 HaRv. L. REv. 347 (1974).

${ }^{64}$ See supra text accompanying notes 43-46.

os See, e.g., Currie, Selected Essays, supra note 31, at 81-82; Cheatham \& Reese, supra note 20, at 961; Sedler, supra note 53, at 201.
} 
ence reflected in forum law is not so strong as to render implausible the notion that the state's lawmakers could intend it to give way to another policy in a multistate case, a court appropriately would opt under Step 3 for nonforum law. Under the circumstances, a choice of forum law would give undue weight to a policy balance struck with intrastate cases paramount in mind.

In considering whether the three conditions specified in Step 3 are met, courts should be particularly attentive to protecting justified expectations and serving the needs of the interstate and international systems, because these policies seem far more likely than any others to justify departing from forum law. ${ }^{68}$ On the other hand, courts should be highly unreceptive to arguments that either the traditional rules, Currie-style interest analysis, or Professor Leflar's "better rule of law" factor ${ }^{67}$ justifies a choice of nonforum law. Very briefly, any reference under Step 3 to the traditional rules is unwarranted for reasons along the lines of those indicated above in my criticism of the place-of-wrong reference in Rules 2 and $3{ }^{68}$ Any reference under Step 3 to standard interest analysis is unwarranted because the choice-of-jurisdiction step in my approach "does what interest analysis is supposed to do and does it better." ${ }^{\text {"日 }}$ And any reference under Step 3 to better rule of law is unwarranted because: (1) a court cannot prefer nonforum law as "better" than a local statute without overstepping local principles of separation of powers and legislative supremacy; (2) a court cannot sensibly prefer nonforum law as "better" than local common law without overruling the local common law to bring it into conformity with the "better" nonforum law; and (3) a court cannot prefer nonforum law as "better" than either a local statute or local common law without generating differences in treatment

\footnotetext{
- See Simson, supra note 20, at 291-94. Because the 1991 article does not attempt to list the needs of the interstate and international systems that may warrant serious attention, my proposal shares some of the potential for inconsistent application for which I criticized the Rule 3 exception for impairments of the multistate system. See supra text accompanying note 21. However, by focusing on needs of the interstate and international systems only when they militate strongly in favor of a choice of nonforum law, my proposal avoids the criticism that I leveled at the Rule 3 exception based on its lack of any limitation to serious impairments. For an attempt to shed light on the circumstances in which the policy of serving interstate and international needs militates strongly in favor of choosing nonforum law, see Simson, supra note 32 , at ch. 5 .

${ }^{67}$ See Leflar, supra note 20, at 295-304.

os See Simson, supra note 20, at 295; supra text accompanying notes $40-42,50$.

Simson, supra note 20, at 295.
} 
[Vol. 56

among litigants that are extremely problematic under the federal Constitution's Equal Protection Clause. ${ }^{70}$

In closing, I emphasize an important common ground between my approach and the New York Court of Appeals' in Babcock. Although my approach defines state interests quite differently than the Babcock court did and differs from the Babcock approach in various other respects, it shares with that approach a commitment to the idea that careful consideration of state interests is central to a rational and just system of choice of law. For this reason, I suggest my approach here not simply as a preferred method of choice of law but also as a very logical evolution from the Babcock approach-something that the rules offered in Neumeier were claimed to be but were not.

${ }^{10}$ U.S. ConST. amend. XIV, § 1; see Simson, supra note 20, at 296-97; Simson, State Autonomy, supra note 40 , at $85-86$. 